\title{
Effects of Helicobacter pylori on histamine and carbachol stimulated acid secretion by human parietal cells
}

\author{
H Jablonowski, K J Hengels, N Kraemer, G Geis, W Opferkuch, G Strohmeyer
}

\begin{abstract}
Helicobacter pylori ( $H$ pylori) infection is associated with hypo, normal, and hypersecretory disorders of the gastric mucosa. Pathophysiological pathways by which $\mathrm{H}$ pylori interacts with acid secretion are still unclear. The effects of $\mathrm{H}$ pylori on $\left({ }^{14} \mathrm{C}\right)$ aminopyrine uptake by human parietal cells were examined as an indirect assay for acid secretion. Isolated oxyntic glands were stimulated with submaximal concentrations of histamine or carbachol and incubated with sonicates of different $H$ pylori strains. Omeprazole and sonicates of Campylobacter jejuni served as positive and negative controls, respectively. Two of four $\boldsymbol{H}$ pylori strains reduced hydrochloric acid sequestration within the parietal cells significantly and in a dose dependent manner in up to $80 \%$. Interaction with acid secretion may therefore constitute a factor contributing to a distinct pathogenicity of $H$ pylori strains.
\end{abstract}

(Gut 1994; 35: 755-757)

Helicobacter pylori ( $H$ pylori) causes or is at least associated with different clinical and histological entities such as chronic gastritis, peptic ulcer disease, and even gastric carcinoma. Under these conditions acid secretion varies from hypo to hyperchlorhydria. Recently it has been shown that sonicates of $H$ pylori strongly inhibit acid secretion by rabbit parietal cells. ' Rabbits, however, are not natural hosts of $H$ pylori. In humans $H$ pylori infection may cause acute epidemic gastritis associated with hypochlorhydria. ${ }^{2-4}$ Whether hypochlorhydria occurs in every short term $H$ pylori infection is as unknown as the influence of longterm $H$ pylori infection on parietal cell function. We have examined the effects of sonicates of different $H$ pylori strains on acid secretion from isolated human oxyntic glands, using ${ }^{14} \mathrm{C}$-aminopyrine $\left({ }^{14} \mathrm{C}\right.$-AP) uptake by the parietal cells. This well established assay indirectly reflects acid production.

\section{Methods}

\section{ISOLATED OXYNTIC GLAND PREPARATION}

Isolated gastric glands were prepared from patients who had had an endoscopic biopsy and who gave informed consent before the investigation. Six to 10 biopsy specimens were taken $10 \mathrm{~cm}$ aboral from the cardia using a GIF XQ 10 or XQ 20 endoscope and an FB 19K biopsy forceps (Olympus). All patients had a negative HLO-test (Delta West). Only data from patients $(n=12)$ with histologically normal oxyntic mucosa who had not taken any drugs inhibiting or buffering acid secretion during the last week were evaluated. The specimens were immediately taken to the laboratory in cold $\left(4^{\circ} \mathrm{C}\right)$ phosphate buffered saline. According to the method of Fellenius ${ }^{5}$ the specimens were minced, washed twice in phosphate buffered saline, and treated with collagenase (Collagenase type I, Sigma) for 120 minutes. Then the solution was filtered to separate the glands from the connective tissue. The glands were washed in respiration medium containing human albumin $(1 \mathrm{mg} / \mathrm{ml})$ and glucose ( $2 \mathrm{mg} / \mathrm{ml}$ ). After removing the supernatant, $0.5 \mathrm{ml}$ concentrated glands were resuspended in $3 \mathrm{ml}$ respiration medium. One hundred $\mu \mathrm{l}$ of this suspension containing $100-300 \mu \mathrm{g}$ glands (dry weight) were incubated with $3 \times 10^{-4} \mathrm{M}$ histamine (Sigma, Lot 49F5002) or with $10^{-4} \mathrm{M}$ carbamylcholine chloride (Sigma, Lot 39T0478) and with sonicates of 2,4 , or 6 mio colony forming units (CFU) $\mathrm{H}$ pylori in addition to ${ }^{14} \mathrm{C}$ aminopyrine. Incubations with omeprazole $\left(3 \times 10^{-8} \mathrm{M}\right)$ and sonicates of Campylobacter jejuni ( 4 mio CFU) served as positive and negative controls. The isolated gland preparation of each patient $(n=12)$ was aliquoted for the following ${ }^{14} \mathrm{C}$-aminopyrine uptake tests: native (2 tests), stimulation (4 tests), $H$ pylori strain A-D (8 tests), omeprazole (2 tests), and Campylobacter jejuni (2 tests). Accordingly, each gland preparation was tested for adequate stimulation with histamine and carbachol as well as for the effect of $H$ pylori/Campylobacter jejuni, and omeprazole on histamine and carbachol stimulated parietal cell secretion.

HELICOBACTER PYLORI PREPARATIONS

Four fresh isolates conforming to standard phenotype criteria for $H$ pylori were grown for 72 hours at $37^{\circ} \mathrm{C}$ in $\mathrm{BHI}$ medium under microaerophilic conditions. Bacteria were suspended in phosphate buffered saline $\left(10^{-8} \mathrm{CFU} / \mathrm{ml}\right)$. Suspensions of $H$ pylori and of Campylobacter jejuni were subjected to a $4 \times 30$ seconds sonification before they were tested in the isolated gland preparations. In addition sonicates of $H$ pylor strain A were incubated with $50 \mu \mathrm{g} / \mathrm{ml}$ pronase $\mathrm{E}$ Typ XXV (Sigma) for 30 minutes at $37^{\circ} \mathrm{C}$ or with $50 \mu \mathrm{g} / \mathrm{ml}$ trypsin (Merck) for 12 hours at $20^{\circ} \mathrm{C}$ or were heat treated for 30 minutes at $100^{\circ} \mathrm{C}$.

\section{PARIETAL CELL FUNCTION}

After 120 minutes incubation at $37^{\circ} \mathrm{C}$ with the respective stimulant/inhibitor the glands were centrifuged and the supernatant was withdrawn. 


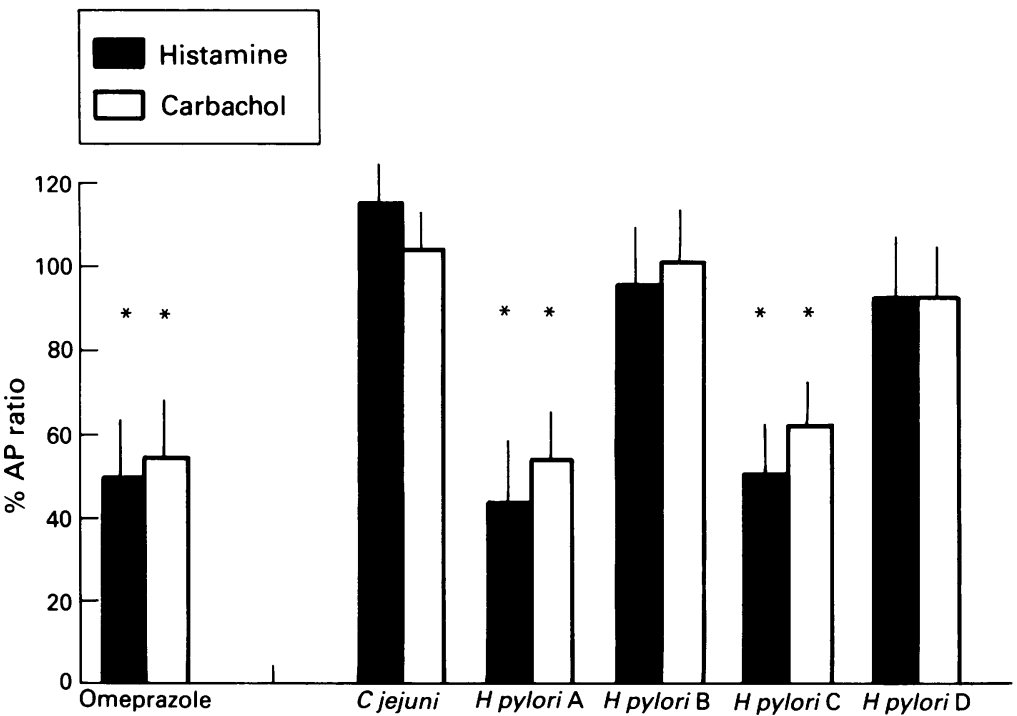

Figure 1: Percentage ${ }^{1+} \mathrm{C}$ aminopyrine $(A P)$ ratio (mean $(S D)$ ) of histamine $(300 \mu M)$ or carbachol $(100 \mu \mathrm{M})$ stimulated gastric glands. Comparison of four different $\mathrm{H}$ pylori strains, Campylobacter jejuni ( 4 mio colony forming units) and omeprazole $(30 \mu \mathrm{M})$ ${ }^{\star} p<0.05$.

Glands were dried, weighed, and solubilised in sodium dodecyl sulphate (SDS, Bio Rad). Intracellular acidification was determined by ${ }^{14} \mathrm{C}$ aminopyrine $\left(10^{-6} \mathrm{M} ; 94,7 \mathrm{mCi} / \mathrm{mmol}\right.$ Dupont $)$ uptake into the parietal cells. The ratio between ${ }^{14} \mathrm{C}-\mathrm{AP}$ in the intraglandular and the extraglandular compartment $(\mathrm{AP}$ ratio $=$ dpm pellet $X$ $100 / 2 \times$ dry weight pellet $\times$ dpm supernatant) was

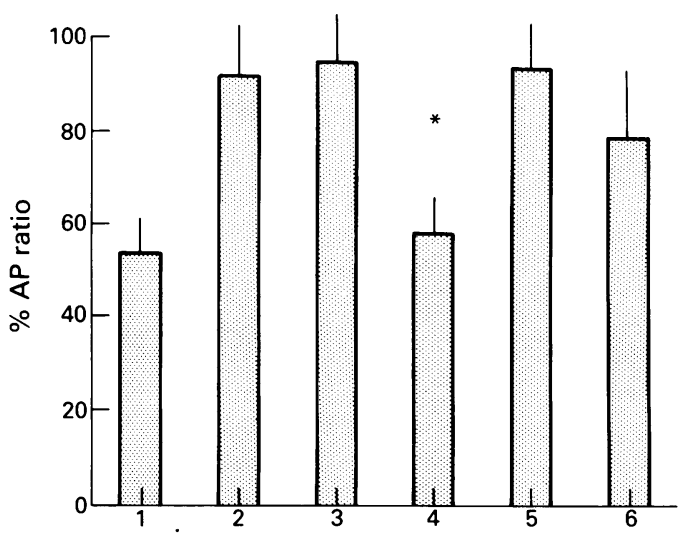

Figure 3: Percentage ${ }^{1+} \mathrm{C}$ aminopyrine $(A P)$ ratio (mean $(S D))$ of histamine $(300 \mu M)$ stimulated gastric glands. $I=$ not histamine stimulated; $2=$ histamine + pronase $(5 \mu \mathrm{g} / \mathrm{ml})$; $3=$ histamine + trypsin $(5 \mu \mathrm{g} / \mathrm{ml}) ; 4=$ histamine + trypsin treated $\mathrm{H}$ pylori sonicate ( 4 mio colony forming units $(C F U)$ $\mathrm{H}$ pylori $A) ; 5=$ histamine + pronase treated $\mathrm{H}$ pylori sonicate (4 mio $C F U \mathrm{H}$ pylori $A$ ); $6=$ histamine + heat treated $\mathrm{H}$ pylori sonicate $\left(4\right.$ mio $C F U \mathrm{H}$ pylori $A$ ). ${ }^{\star} p<0.05$. used as an estimate of acid production by the parietal cells. ${ }^{5}$ Radioactivity of the samples was counted in a United Technologies Packard 2000CA scintillation counter.

\section{CELL VIABILITY}

To rule out cytotoxic effects, trypan blue exclusion tests and triciated leucin incorporation tests as indirect parameter of protein synthesis were performed in each experiment.

\section{STATISTICS}

Because the data had a Gaussian distribution and the standard deviations were roughly equal, the results were analysed by Student's $t$ test for paired data. A p value $<0.05$ was considered to be significant.

\section{Results}

As determined by dye exclusion tests and leucin

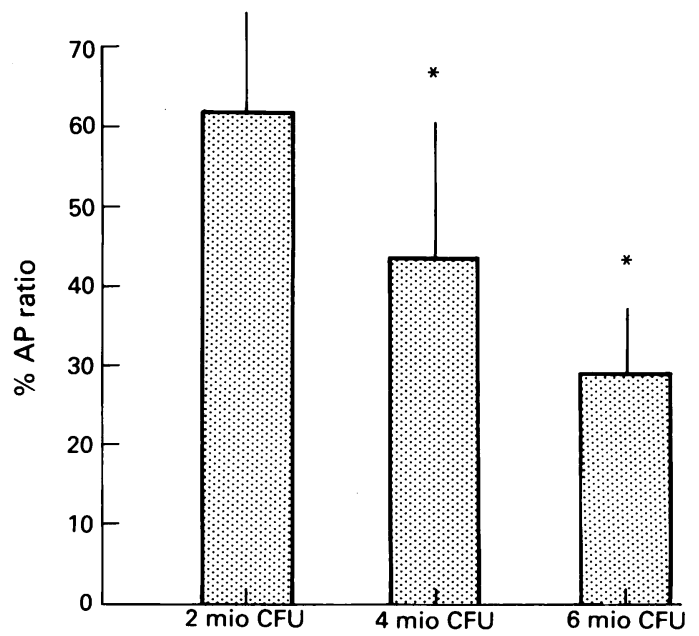

incorporation assays neither $H$ pylori or Campylobacter jejuni sonicates had any effect on cell membrane integrity and protein synthesis of the oxyntic glands. Histamine and also carbachol (mean (SD)) stimulated ${ }^{14} \mathrm{C}$-AP uptake by 92 (18)\% and $41(14) \%$, respectively. Omeprazole inhibited both histamine and carbachol stimulated ${ }^{14} \mathrm{C}$ aminopyrine uptake by $49(13) \%$ and 54 (12)\% whereas sonicates of Campylobacter jejuni had no effect. Two of the four tested $H$ pylori sonicates from different strains inhibited cellular acidification of the parietal cells significantly (Fig 1). This inhibitory effect on the parietal cells was in a dose dependent manner (Fig 2) and was seen in both the histamine as well as in the carbachol stimulated system. The maximal reduction of the histamine and carbachol stimulated parietal cell acidification was $80 \%$ and $64 \%$ for $H$ pylori A (6 mio CFU) and $62 \%$ and $66 \%$ for omeprazole $\left(3 \times 10^{-8} \mathrm{M}\right)$, respectively. Heat treatment of strain A for 30 minutes at $100^{\circ} \mathrm{C}$ reduced the acid inhibitory effect by about $50 \%$. Digestion with pronase eliminated the inhibition totally, whereas trypsin pretreatment of the sonicates resulted in unchanged inhibitions (Fig 3).

\section{Discussion}

Support for the assumption that $H$ pylori can affect gastric acid secretion in humans is derived from the clinical finding that under certain circumstances the bacterium may cause acute epidemic gastritis with transient hypochlorhydria $^{2-4}$ and from in vitro experiments showing an inhibiting effect of $H$ pylori on acid production by isolated rabbit parietal cells. ${ }^{1}$

Our study shows for the first time that $H$ pylori isolated and cultured from infected patients contains a factor that strongly suppresses acid secretion from oxyntic glands of $H$ pylori negative people with normal gastric histology and that this capability differs between $H$ pylori strains. Because only fresh strains of $H$ pylori were used the lack of inhibitory activity seen in two of the strains cannot be attributed to repeated subculture. The nature of the inhibitor and its cellular localisation remain to be defined. Pre-
Figure 2: Percentage ${ }^{14} \mathrm{C}$ aminopyrine $(A P)$ ratio (mean $(S D)$ ) of histamine $(300 \mu \mathrm{M})$ stimulated gastric glands. Comparison of 2,4 , and 6 mio colony forming units $(C F U) \mathrm{H}$ pylori of strain $A .{ }^{\star} p<0.05$. 
liminary data suggest that the factor inhibiting acid secretion from rabbit parietal cells is a protein larger than $12-14000 \mathrm{kDa} .^{1}$ Our data support the assumption that the inhibitor is a rather heat stable protein. A precise characterisation and comparison of the factor(s) inhibiting rabbit and human parietal cells, however, is mandatory to prove or refute identity and to gain some insights into their mode of action. As preparations of isolated glands parietal cells have lost their polarity, the site and mode of action of inhibition remain to be determined. Under our experimental conditions the two $H$ pylori strains that contained the inhibitor suppressed histamine as well as carbamylcholine stimulated acid secretion. Therefore, it does not seem probable that the acid inhibitor interferes with either the histamine or the acetylcholine receptor of the parietal cell but rather blocks acid secretion by a different mechanism. To further elucidate the mode of action it would be interesting to find out if the inhibitor is membrane bound or cytoplasmatic and thereby possibly released by the germ.

Pathogenetic or even clinical implications of our findings must be entirely speculative at this point. Further studies are needed to find out if acid inhibition is a factor facilitating gastric colonisation and contributing to a distinct pathogenicity of different $H$ pylori strains. $H$ pylori infection has been shown to be associated with hypo, normal, and hyperchlorhydria and with inappropriate hypergastrinaemia. ${ }^{6}$ Hypergastrinaemia seems to be caused by $H$ pylori or by interference of $H$ pylori with the somatostatin mediated inhibition of gastrin release from the antral G-cells. ${ }^{8}$ After $H$ pylori eradication serum gastrin concentrations decrease ${ }^{9}$ but acid secretion tends to remain unchanged. ${ }^{10}$ One of the possible explanations for this finding is the blockade of the surplus gastrin effect on the parietal cell by the $H$ pylori derived acid inhibitor. On the other hand an infection of a subject with an $H$ pylori strain devoid of the acid inhibitor could lead to hypergastrinaemia driven acid hypersecretion. The differential expression of an acid inhibiting factor by the different strains could prove to be a key factor of $H$ pylori pathogenicity but we are just at the beginning of testing this hypothesis.

1 Cave DR, Vargas M. Effect of a Campylobacter pylori protein on acid secretion by parietal cells. L ancet 1989; ii: 187-9.

2 Ramsey EJ, Carey KV, Peterson WL. Epidemic gastritis with hypochlorhydria. Gastroenterology 1979; 76: 1449-57.

3 Gledhill T, Leicester RJ, Addis B. Epidemic hypochlorhydria. BMF 1983; 290: 1383-6.

4 Morris A, Nicholson G. Ingestion of Campylobacter pyloridis causes gastritis and raised fasting gastric $\mathrm{pH}$. Am $\mathcal{F}$ Gastroenterol 1987; 82: 192-9.

5 Fellenius E, Elander B, Wallmark B, Haglund U, Helander $H$ Olbe L. A micro-method for the study of acid secretory function in isolated oxyntic glands from gastroscopic biopsies. Clin Sci 1983; 64: 423-31.

6 Smith JT, Pounder R, Nwokolo C, Lanzon-Miller S, Evans D, Graham D. Inappropriate hypergastrinaemia in asymptomatic healthy subjects infected with Helicobacter pylori. Gut 1990; 31: 522-5.

7 Tsujii N, Kawato S, Tsujii S, Ito T, Sakasi Y, Nagano K, et al. Changes in serum and mucosal gastrin levels following antral Changes in serum and mucosal gastrin levels following antral A706.

8 Hamura K, Sumii K, Okamato S, Yoshihara M, Tari A, Teixeira CR, et al. Helicobacter pylori infection causes low antral somatostatin content: pathogenesis of inappropriate hypergastrinemia. Gastroenterology 1992; 4: A80

9 Graham DY, Opekum A, Lew GM, Evans DJ, Klein PD. Evans DG. Ablation of exaggerated meal-stimulated gastri release in duodenal ulcer patients after clearance of Helicobacter (Campylobacter pylori) infection. Am $\mathcal{F}$ Gastroenterol 1990; 85: 111-5.

10 McColl KEL, Fullarton GM, Chittajalu R, Nujumi AM, Macdonald AMI, Dahill SW, et al. Plasma gastrin, daytime intragastric $\mathrm{pH}$, and nocturnal acid output before and at 1 and 7 months after eradication of Helicobacter pylori in duodenal ulcer subjects. Scand f Gastroenterol 1991; 26: 339-46. 